\title{
TRPC3 overexpression promotes angiotensin II-induced cardiac dysfunction
}

\author{
Bernhard Doleschal ${ }^{1}$, Stefan Wolf ${ }^{1}$, Marie-Sophie Huber ${ }^{1}$, Gerald Wölkart ${ }^{1}$, Gudrun Antoons ${ }^{2}$, Klaus Groschner ${ }^{3^{*}}$ \\ From 18th Scientific Symposium of the Austrian Pharmacological Society (APHAR). Joint meeting with the \\ Croatian, Serbian and Slovenian Pharmacological Societies. \\ Graz, Austria. 20-21 September 2012
}

\section{Background}

TRPC3 was recently demonstrated as a player in pathogenesis of cardiac hypertrophy, while the potential proarrhythmogenic role of TRPC3 is incompletely understood. Using a TRPC3 transgenic overexpression mouse model, we examined the involvement of TRPC3 in cardiac actions of angiotensin II (AngII).

\section{Methods}

AngII effects on cardiac functions were characterized in Langendorff perfused hearts. Single ventricular myocytes were isolated and field-stimulated to measure effects on sarcomere shortening and $\mathrm{Ca}^{2+}$ transients. Furthermore, L-type $\mathrm{Ca}^{2+}$ channel current, action potentials and nonselective ion currents were analyzed electrophysiologically.

\section{Results}

AngII (100 nM) reduced left ventricular pressure (LVP) within $2 \mathrm{~min}$ to $64 \%,+\mathrm{dP} / \mathrm{dt}$ to $50 \%$ and $-\mathrm{dP} / \mathrm{dt}$ to $55 \%$ of control in TRPC3(+/-) hearts, while even producing a positive inotropic effect in wild-type (WT) hearts. Simultaneously, ECG recordings demonstrated AngII-induced episodes of acute arrhythmogenicity in all TRPC3(+/-) hearts $(n=6)$, whereas rhythm of WT hearts $(n=6)$ remained unaffected. The AngII-induced impairment of cardiac functions in TRPC3(+/-) hearts was partially reversed by Pyr3 $(30 \mu \mathrm{M})$. The amplitude of $\mathrm{Ca}^{2+}$ transient was significantly higher $(\mathrm{p}<0.05 ; \mathrm{n}=60)$ in myocytes from TRPC3(+/-) mice $\left(\left[\mathrm{Ca}^{2+}\right] \mathrm{F} / \mathrm{F}_{0} 0.354 \pm 0.024\right)$ as compared to WT $\left(\left[\mathrm{Ca}^{2+}\right] \mathrm{F} / \mathrm{F}_{0} 0.262 \pm 0.021\right)$. Also, the time constant $(\tau)$ of $\mathrm{Ca}^{2+}$ decline was different between WT $(0.196 \pm 0.009 \mathrm{~ms} ; \mathrm{n}=61)$ and TRPC3(+/-) $(0.170 \pm$ $0.008 ; \mathrm{n}=67 ; \mathrm{p}<0.05)$. Sarcomere shortening showed no

\footnotetext{
* Correspondence: klaus.groschner@medunigraz.at

${ }^{3}$ Institute of Biophysics, Medical University of Graz, 8010 Graz, Austria

Full list of author information is available at the end of the article
}

significant difference between the two groups (3.80 \pm $0.69 \%$ vs. $3.52 \pm 0.65 \% ; \mathrm{n}=10$ ) whereas the SR-loading estimated from rapid application of caffeine $(20 \mathrm{mM})$ revealed an increased SR loading of up to $40 \%$ in TRPC3 $(+/-)$ myocytes as compared to WT $(\mathrm{p}<0.05 ; \mathrm{n}=43)$. The time constant of $\mathrm{Ca}^{2+}$ decline during caffeine challenge was also significantly changed $(\mathrm{p}<0.05)$ in TRPC3 $(+/-)$ myocytes $(3.04 \pm 0.44 \mathrm{~ms} ; \mathrm{n}=11)$ as compared to WT cells $(1.65 \pm 0.158 \mathrm{~ms} ; \mathrm{n}=16)$. Importantly, AngII $(100 \mathrm{nM})$ induced a rise in diastolic $\mathrm{Ca}^{2+}$ levels, which was accompanied by irregular contractions in TRPC3(+/-) but not in WT myocytes. The rise in the diastolic $\mathrm{Ca}^{2+}$ levels was significantly suppressed by $\operatorname{Pyr} 3(10 \mu \mathrm{M} ; \mathrm{n}=16)$, SEA $0400(1 \mu \mathrm{M} ; \mathrm{n}=14)$ and $\mathrm{KN}-93(1 \mu \mathrm{M} ; \mathrm{n}=12)$. Electrophysiological characterization of L-type voltage-gated $\mathrm{Ca}^{2+}$ currents and action potentials revealed that baseline electrophysiological parameters were not affected by TRPC3 overexpression, while AngII induced a transient prolongation of action potential duration only in TRPC3(+/-) myocytes. This TRPC3-dependent response was associated with a higher incidence of delayed afterdepolarizations.

\section{Conclusions}

Our results demonstrate that AngII modulation of cardiac functions is strictly dependent on TRPC3 expression and suggest a key role of TRPC channels in AngIImediated arrhythmogenicity.

\footnotetext{
Acknowledgements

Supported by the Austrian Science Fund FWF and the International PhD Program Metabolic and Cardiovascular Disease DK-MCD.

\section{Author details}

'Department of Pharmacology and Toxicology, Institute of Pharmaceutical Sciences, University of Graz, 8010 Graz, Austria. ²Division of Cardiology, Medical University of Graz, 8036 Graz, Austria. Institute of Biophysics, Medical University of Graz, 8010 Graz, Austria.
} 
doi:10.1186/2050-6511-13-S1-A83

Cite this article as: Doleschal et al:: TRPC3 overexpression promotes angiotensin II-induced cardiac dysfunction. BMC Pharmacology and Toxicology 2012 13(Suppl 1):A83.

Submit your next manuscript to BioMed Central and take full advantage of:

- Convenient online submission

- Thorough peer review

- No space constraints or color figure charges

- Immediate publication on acceptance

- Inclusion in PubMed, CAS, Scopus and Google Scholar

- Research which is freely available for redistribution

Submit your manuscript at www.biomedcentral.com/submit 